\title{
The Conceptual Foundations of Lifelong Learning in Kazakhstan: Process Modeling
}

\author{
https://doi.org/10.3991/ijet.v16i17.23685 \\ Serik Omirbayev, Darkhan Akhmed-Zaki, Aidos Mukhatayev( $\left.{ }^{(}\right)$, \\ Andrii Biloshchytskyi, Khanat Kassenov, Adil Faizullin \\ Astana IT University, Nur-Sultan, Kazakhstan \\ aidos.mukhatayeveastanait.edu.kz
}

\begin{abstract}
Considering the increased interest in ensuring the well-being of a person, lifelong learning takes a leading place in society. The aim of the research is to build the concept of LLL system for Kazakhstan based on the methodology of education and international best practices. The key idea of the research is to justify the LLL system, that provides coverage of the country's population with formal, non-formal and informal education to increase its competitiveness and basic competencies to the level of the OECD countries. To do this, we propose mechanisms that allow us to fully recognize the learning outcomes of formal, non-formal and informal education.

The ideas were proposed by the authors to the Kazakhstan's Government on the creation of the Concept of Lifelong Learning.
\end{abstract}

Keywords-Lifelong learning, Recognition of learning outcomes, personal competence, formal education, non-formal education, non-formal education

\section{Introduction}

One of the most relevant trends of our time is lifelong learning (LLL). Firstly, the process of updating knowledge and technologies is accelerating, and new scientific fields are emerging. It is essential to change the functional literacy of people and constantly retrain them in accordance with the new challenges of the digital economy.

Secondly, the dynamic development of society creates a rapidly changing labor market and leads to an increasing gap between the requirements of employers and qualifications. In this connection, there is a need for constant updating of professionally relevant knowledge, skills, and competencies, as well as flexible changes or transfer from one professional sphere to another.

Accordingly, we should create a system of lifelong learning that involves receiving education through all types of education.

Lifelong learning will allow you to achieve personal development, that is, the realization of life goals and values; secondly, to obtain a certain social status and, thirdly, to gain access to the profession in the most optimal way for the individual. 
Lifelong learning is a paradigm aimed at creating opportunities for all citizens of Kazakhstan to learn according to their needs and abilities, for their worthy self-realization in society.

Lifelong learning is considered at the international level as one of the main ways to ensure a decent human life, for example, mentioned in Goal 4 of the 2030 Agenda for Sustainable Development [1]. International Standard Classification of Education (ISCED, 2011) [2] officially defined the concepts of formal, non-formal and informal education.

The UNESCO Institute for Lifelong Learning, in its "Lifelong Learning" Technical Note [3], focuses on all forms of education and learning throughout a life.

At World Education Forum "Education 2030", in Incheon (2015), a transformative concept of education was formulated. The Incheon Declaration [4] calls on States to provide inclusive and quality education on an equal basis, as well as to provide everyone with the opportunity to receive lifelong education.

Lifelong learning is becoming an essential trend in the development of society and economy, as well as the well-being of citizens (Paris Communique-2018) [5].

In March 2000, at the European Council held in Lisbon, the Memorandum on Lifelong Learning was adopted [6], the main idea of which was that lifelong learning became the fundamental principle of the educational system.

Since 2001, the highest body of the Bologna Process, the Conference of Ministers, has included lifelong learning in its agenda, and in 2005 the Qualifications Framework of the European Higher Education Area was developed [7] and in 2008 - the European Qualifications Framework for LLL [8].

The UN, in its Concept Note "Education in the Age of Covid-19 and Beyond" (2020) [9], notes that the pandemic crisis and unprecedented disruptions in the functioning of the education system have exacerbated existing educational problems. The disruption of the educational process has and will have serious devastating consequences beyond the educational system. However, it is noted that the crisis has stimulated innovation within the education sector, especially in ensuring the continuity of education and vocational training, especially in obtaining skills and competencies that allow you to provide cross-functionality or perform additional professional functions. This is achieved through non-formal nano-learning or obtaining a micro-qualification.

Thus, it is time to ensure the flexibility of the education system, which implies consistency between the levels and types of education. In this regard, it is actual to establish the relationship, especially in terms of recognition, certification and accreditation of knowledge and skills acquired because of all types of learning.

\section{Methods}

During the study, a range of theoretical methods were applied: content analysis of the conceptual apparatus; comparative analysis of the normative legal acts of countries; study and generalization of advanced pedagogical experience; synthesis of the obtained results of analytical activities. 
Projective methods and specifically the modeling method are used in the process of constructing structural models of LLL processes. The authors referred on the results of scientific research by scientists and international best practices from different countries, as well as on the conclusions of the OECD Skills Strategy Kazakhstan and on the data of the PIIAC study.

\section{Literature review}

The problem of lifelong learning is the subject of research by scientists from different countries. For example, Kapil Dev Regmi [10], after reviewing several relevant fundamental texts of supporters of various schools, in this article argues that the vast majority of approaches are based on two fundamental models: "human capital model" and "humanistic model".

Another study [11] focuses on formal lifelong learning. However, the author recognize that lifelong learning can also be non-formal or informal.

Educational institutions, especially universities, face different challenges: globalization, an aging society; growing competition between higher education institutions, as well as rapid technological processes. According to Constanta Aurelia Chitiba [12], in order to successfully solve all these problems, traditional universities must transform themselves by adopting a system of lifelong learning. This system will change the way universities currently teach.

The studies examine the different models of the "knowledge economy/society" that can be recognized both in the world and in EU [13].

In this regard, the experience of Hong Kong, where the Institute of lifelong learning for Elder people was established in 1998 to meet their growing need for training, is also indicative [14] and the experience of Australia [15], which is also consistent with the paradigm of the emerging "knowledge-based economy".

LLL in China is viewed from the perspective of China's evolving modernization in agriculture, industry, military, and science and technology [16]. Issues related to the distribution of the labor force, qualifications, and training, as well as potential problems are considered.

Charlene Tan [17] examines LLL in Singapore and argues that achieving lifelong learning faces the sociocultural preference for academic rather than vocational education in Singapore.

Curricula and academic content should enable students to participate in stimulating learning experiences, and promote development and learning opportunities throughout their lives and careers. [18]. In addition, the fast pace of technological change requires a concomitant increase in the ability to acquire new competencies [20].

One of the trends pushing for more active development of LLL is the digitalization of the economy and society. According to the authors [21] traditional TVET models that view formal training as the ultimate goal will not prepare workers for the everchanging world of work in an era of technological transformation. 
In an LLL organization, both the learning process itself and recognition of learning outcomes are important as well as its assessment. Therefore, this issue is also the subject of separate studies. In particular, the paperwork [22] proposes generic evaluation methodology for the specific case of lifelong learning systems.

The articles are devoted to the forms and means of implementing LLL. According to the article [23] effective organization of the educational process in the conditions of rapid acceleration of the digitalization of society is impossible without increasing its digital literacy.

The methodological competence of teachers plays a special role in the establishment of digital literacy of the population [24]. The following works [25], [26], [27] state that the necessity of using ICT and e-portfolio to improve the LLL process is justified. This task statement is particularly relevant in the context of a pandemic.

As shown by the analysis of the literature on the problem, the researchers focus on the fact that LLL, as a tool for ensuring human well-being, is considered as one of the main factors in the development of the economy of countries. To use this potential, countries plan to regulate the processes, defining their conceptual foundations (this will be discussed in more detail in the next section).

\section{$4 \quad$ International experience: strategies and tactics of $L L L$ organization}

In France, in 2002, the Law “On Social Modernization” was adopted [28], which introduced the concept of "validation of knowledge acquired through experience".

Belgium [29], Denmark [30], Estonia [31], Ireland [32], the Netherlands [33], Norway [34], Portugal [35], Romania [36], Slovenia [37], Spain [38], and the United Kingdom [39] have developed their strategies and practices to systematically identify and recognize non-formal learning outcomes, frameworks and legal structures supporting recognition procedures, and use recognition as a mechanism to support lifelong learning.

As early as 1976, the USA Law on Lifelong education was adopted [40], the implementation of which was carried out through 19 programs covering both adult education, and the development of the needs of the family, and personal development. At present, LLL is the interconnection of all levels of education and is based on ensuring accessibility to all types of education, flexibility, variability of the education system and involves increasing the costs of all levels of LLL.

In Finland, the citizens' right to receive non-formal education recognition is called "previously received training" and is provided for by law [41]. The qualification requirements are set by the National Board of Education. Accordingly, the final decision on the assignment of qualifications is accepted by the National Qualifications Committee. In case of a negative decision, a set of modules is determined for a candidate, which must be learned additionally. 
Australia [42], Singapore [43] and Scotland [44] have the most developed system of lifelong education, an improved national qualifications framework that covers all professional and higher education qualifications, and a legislative framework governing the certification and certification of qualifications.

The South Korea has advanced experience in implementing a cumulative learning system, which involves adding new knowledge and skills to existing ones, which are considered when calculating credits to recognize the learning outcomes and certification. In this connection, the National Institute for Lifelong Education was established [45].

Thus, international experience shows that with the growing need for continuous acquisition or updating of knowledge, methods and institutions are being introduced to evaluate and recognize learning outcomes. The involvement of the adult population in LLL is becoming one of the indicators of human capital development. Accordingly, the role of non-formal education organizations is gradually being equalized with formal education organizations.

\section{$5 \quad$ Analysis of the current situation}

Now, Kazakhstan has developed and applies the requirements for the assignment and recognition of qualifications for professions. The state authorities determine the occupation or type of activity, the implementation of which is possible only if there is a certification or official permission.

Independent certification of the qualifications of specialists in technical and vocational education (ISCED level 4) is carried out. To ensure this, the National Chamber of Entrepreneurs of Kazakhstan maintains a Register of certification centers for specialists [46]. A specialist certification center is a division under a legal entity or an industry association (union), an individual entrepreneur or a legal entity that determines the level of qualification (ability) of specialists to perform work within the relevant type of professional activity. That is, certification and recognition of the qualifications of specialists are carried out in different ways for regulated and unregulated activities.

Professional staff is the key to the success of the organization. Therefore, maintaining the compliance of the professional level of employees with dynamically increasing qualification requirements becomes one of the tasks of the employer.

Kazakhstan has developed a sector of non-state providers of non-formal education. According to a UNESCO study (2018), the non-formal education sector is filled with many non-governmental providers, including private businesses, non-governmental organizations, youth organizations, and trade unions. All of them offer various seminars, courses, retraining, on-the-job training, and individual consultations to the adult population of the country.

However, according to the OECD conclusions, the state does not monitor the quality of services provided by non-formal education organizations. Procedures for licensing, certification, and accreditation of short-term programs and courses are not provided for by the legislation. Accordingly, there are no official statistics on the number of organizations providing non-formal education services. In addition, this situation serves as a 
barrier to the recognition of learning outcomes of non-formal education due to the lack of a system of trust on the part of society, employers, and consumers. The State is obliged to take measures to develop confidence in the internal labor market.

At the same time, data from international studies indicate a low involvement of the adult population in lifelong education. So according to the OECD [47] in 2018, only $17 \%$ of the adult populations (16-65 years old) participated in non-formal education, while the participation rate of women is higher than that of men $(20 \%$ vs. $13.85 \%)$. It means that the participation rate is lower in Kazakhstan than in OECD countries (50\%).

This fact indicates that the skills of the adult population do not correspond to the Strategic goal of Kazakhstan to entry into the Top-30 most competitive countries by 2050 .

Moreover, according to the PIAAC study [48], 50\% of citizens of Kazakhstan reach only the second level of literacy and numeracy proficiency. That is, the critical mass of Kazakhstanis is aimed only at the simple reproduction of knowledge and does not have an innovative potential. A comparison of the skills of Kazakhstanis aged 16-39 years shows that after 26 years, the level of their skills may decrease by $10 \%$ - the next generation of the population over 40 years old may become less qualified than today.

Despite the increase in the number of organizations providing non-formal education in Kazakhstan (according to the World Bank), OECD studies demonstrate that in Kazakhstan a large proportion of the adult population ceases to study after obtaining formal education. Therefore, there is a loss of acquired skills, while the acquisition of new skills becomes more complicated.

According to the World Bank study, Kazakhstan has a relatively low level of participation in non-formal learning provided by businesses. Only $21.8 \%$ of businesses offered training in 2019 , compared to an average of $29.0 \%$ in OECD countries. Thus, $14.7 \%$ of employees in the private sector participated in additional education, and $32.2 \%$ of employees in the public sector [49]. However, in contrast to the OECD countries, in Kazakhstan, women (19.3\%) are more likely to participate in adult education than men $(14.3 \%)$.

The data demonstrate that higher education coverage is not a guarantee of a high level of skills. The PIAAC study revealed that despite the relatively high coverage of higher education, the younger generation of Kazakhstan scored significantly lower than the same generation in the OECD countries [50]. On average, in the OECD countries, the population with higher education aged 25-34 years scores 277 points (literacy proficiency), while in Kazakhstan this indicator is 249 points.

Moreover, PIAAC-2018 identified that only 1/5 of the population aged 16-34 years of the Republic of Kazakhstan has a high level of digital skills.

According to the 2018 National Report "On the state and development of the education system of the Republic of Kazakhstan" [51], the structure of expenditures of the urban and rural population determined territorial differences in access to formal and non-formal education. The urban population spends more on pre-school education $(32.2 \%)$, while the rural population spends more on higher education $(26.2 \%)$. At the same time, in comparison with the urban resident, the rural one spends 7 times more money on adult education. This fact indicates a high need of the rural adult population for additional education. 
According to the OECD, the results of PISA are mirrored in the PIAAC indicators. This means that a low level of basic skills is almost impossible to overcome in adult life.

This can lead to the fact that functionally illiterate citizens who will not study and work after graduation may end up in the NEET group. The more functionally illiterate students there are in the country, the greater the share of NEET and, as a result, the higher the level of social inequality in society.

This data is confirmed by the World Bank report on the project "Skills Development Strategy in Kazakhstan" in 2020. Thus, the data demonstrate that Kazakhstan is trapped in low skills, and a relatively low level of skill application and low labor productivity. Moreover, Kazakhstan has a relatively high number of jobs that are subject to automation. For example, $52 \%$ of jobs in the future will be at high or significant risk of automation, compared to the OECD average of $47 \%$ [52].

As part of the provision of academic independence to universities in 2018 , the legislative documents were developed for the first time, regulating the procedure for recognizing the learning outcomes of non-formal education (unfortunately, the issues of informal education are still open) $[53,54]$.

The Rules define the concepts of "non-formal education", "recognition of learning outcomes", "organizations providing non-formal education", which is important for building a system of lifelong learning. But at the same time, there are significant contradictions that hinder the development of lifelong learning:

1. The procedure for recognizing organizations that provide non-formal education is only defined: regulation of the recognition process.

2. It does not consider the global, international nature of non-formal education (online training, receiving non-formal education in foreign organizations in various forms).

3 . The zone of non-formal education within the country is narrowing (learning outcomes obtained only in registered organizations are recognized).

4. Rules do not allow the recognition of learning outcomes obtained in organizations that are not included in the Register.

These inconsistencies in the regulatory framework indicate an imperfect system of legal regulation that requires thorough improvement.

Thus, the low level of functional literacy of the adult population, combined with low participation in non-formal education and a relatively low level of digital skills, can lead to an increase of low-skilled professionals and the younger generation of the NEET group. The solution to the problem lies in the creation and development of the LLL system.

\section{Results of study}

\subsection{LLL system for Kazakhstan: concept}

The key task is to change the thinking and the formation of people's need for continuous learning, as a factor in increasing the competitiveness in the labor market. For 
LLL to be properly developed in Kazakhstan, it is necessary to create a system of lifelong education that ensures the coverage of the country's population with formal, nonformal and informal education to increase its competitiveness and basic competencies up to the level of the OECD countries. At the same time, by our opinion it should be considered that the creation of such a system should be based on the following principles:

1. free choice of personal learning path and acquisition of skills and competencies through LLL.

2. consistency and complementarity of all forms of education in accordance with the needs of the individual.

3. mobility of labor resources - the possibility of changing the profile of activity and parallel obtaining professional education in various areas.

4. interaction between various institutions (the state, educational organizations, business, and citizens) to ensure a system of lifelong learning.

5. equal value of learning outcomes regardless of the type of educational programs in the framework of formal, non-formal and informal education.

We consider that the achievement of the goals of the Concept and the main objectives of the development of lifelong learning should be provided through the implementation of the following main objectives (Figure 1).

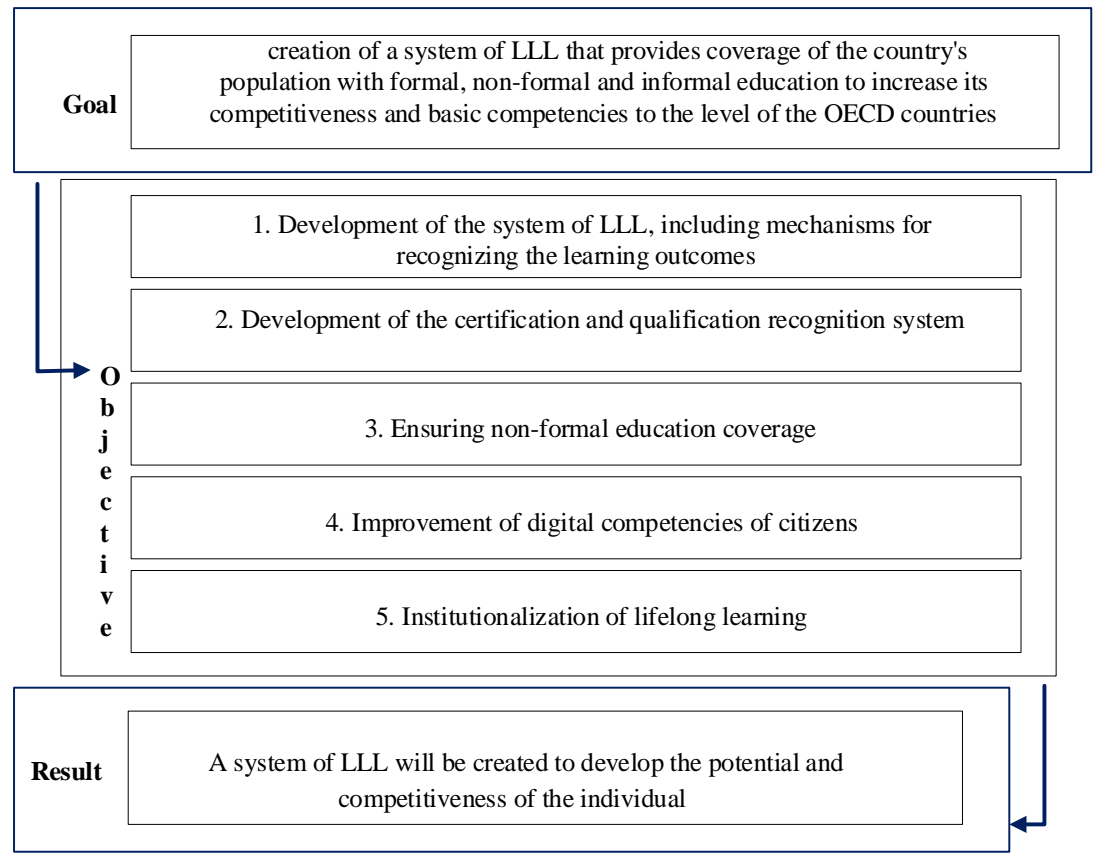

Fig. 1. Targets in the construction of the LLL system 
As you can see in the Figure 1, to create an LLL system, you need to build a logical scheme "Goal-Objective-Result". That is, to achieve the goal (the expected result, therefore), the objectives working for the implementation of the goal are decomposed.

To achieve the demand for specialists in the labor market, it is essential to update the educational programs and revise them considering the National Qualifications System. This will allow us to include the skills and competencies of the previous level of education and avoid duplication of achievements of similar learning outcomes at subsequent levels.

Also, within the framework of this objective, it is necessary to develop mechanisms for recognizing knowledge, skills and competencies obtained through various forms of education (including Mass Open Online Courses) [55].

Based on the Goal and objectives of building the LLL system and positive international experience, its concept can be presented as follows (Figure 2):

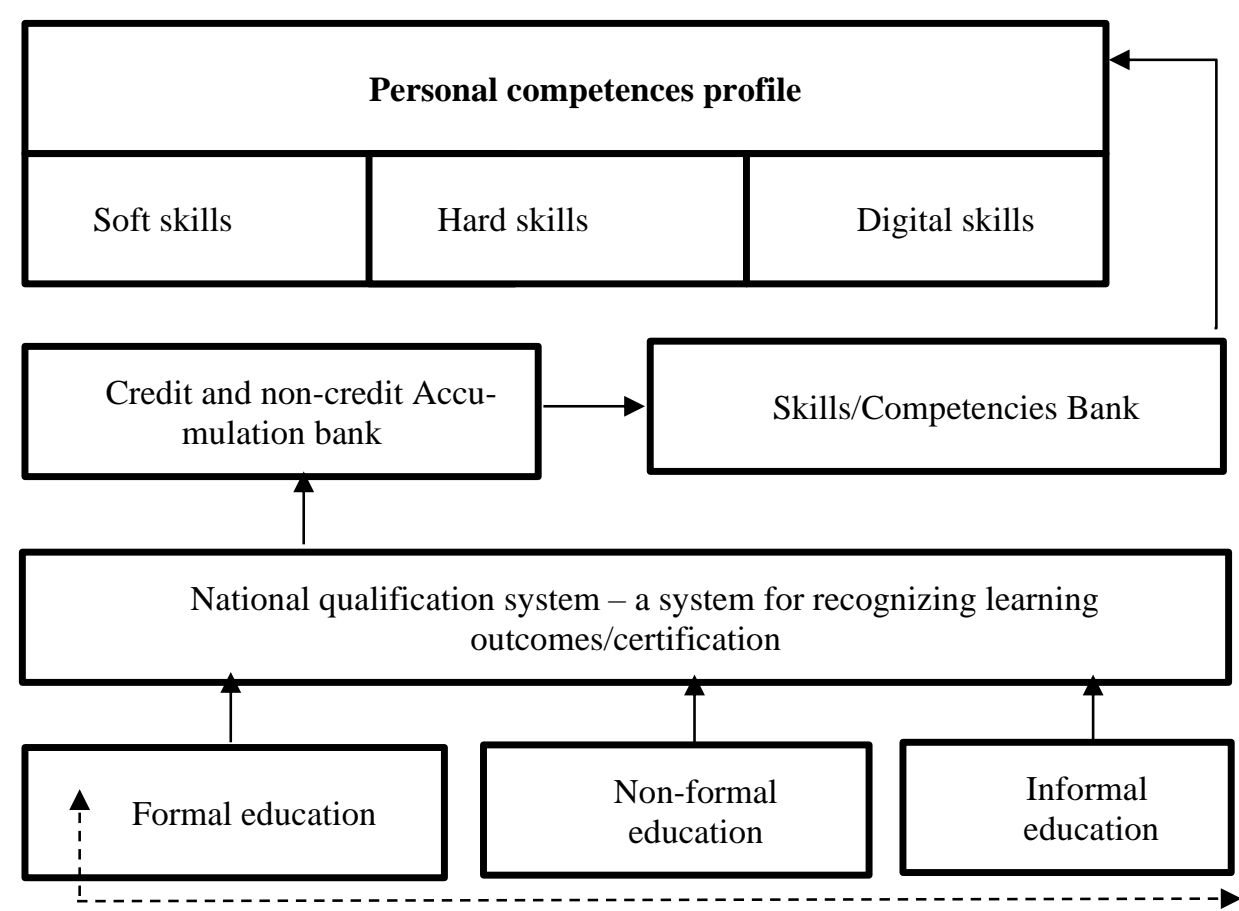

Fig. 2. LLL system concept

The concept is based on the experience of the Credit (accumulation) system, which involves adding new professional competencies to the existing ones, and allowing the acquisition of skills (Stackable degree). The concept is harmonized with the levels of the National Qualifications Framework of Kazakhstan. The vertical dotted arrow indicates vertical integration, which provides an opportunity for a person to learn along the educational trajectory "up", advancing him through the stages and levels of professional education. The horizontal dotted arrow indicates the possibility of 
professional development at any stage of professional activity. Moreover, this will allow, if necessary, not only to continue education, but also to change its profile, using the system of recognition of their learning outcomes.

Within the framework of the concept, through the use of new digital solutions, we propose to introduce two completely new elements for Kazakhstan:

1. Credit and non-credit Accumulation bank (learning outcomes of micro and nanoeducation) for the recognition and confirmation of learning achievements.

2. Bank of skills/competencies, that the profile of the competencies acquired by soft, hard - and digital skills is subsequently formed from bank information.

The logic of the LLL organization involves the implementation of the possibility of acquiring micro-qualifications and learning outcomes of nano-learning ("Nanodegree") at all levels and stages, which will allow one to acquire the necessary professional skills in a short time, create your individual learning trajectory and eliminate knowledge gaps, including inclusive education.

The range of certification courses provided by universities in partnership with companies should be expanded, that will be recognized by the National Qualification System, including those adopted by the world practice of nanodegree, especially in the IT sector.

For the full development of the LLL system, it is necessary to recognize the activities of the growing sphere of the Kazakhstan market of non-formal education - such as Corporate universities and Training and course complexes of enterprises. Their advantage is high mobility and efficiency in the formation of competencies in the target group.

Certification and qualification verification systems should clearly regulate the procedure for recognition of qualifications based on experience, education, and demonstrated knowledge and skills. At the same time, the used approach should be different for regulated and unregulated professions. For regulated professions, the main guarantor of the quality and qualifications conformity should be the state, represented by industry-specific state bodies, and for unregulated professions - a market mechanism, which is based on the trust of employers in the industry.

The application of Professional standards, the Sectoral Qualifications Framework and the National Qualifications Framework is integrated with the qualification validation mechanisms to ensure the full functioning of the National Qualifications Framework. As a result, a system will be created that allows to identify, document, evaluate, certify and transfer learning outcomes of all forms and contexts of lifelong learning.

\subsection{Institutionalization of lifelong learning}

To implement comprehensive measures for the realization of the LLL system in the country, an institutional environment should be created that includes all stakeholders and is coordinated by a single operator. According to the scientific literature and the experience of other countries, we propose to institutionalize LLL as follows (Fig. 3): 


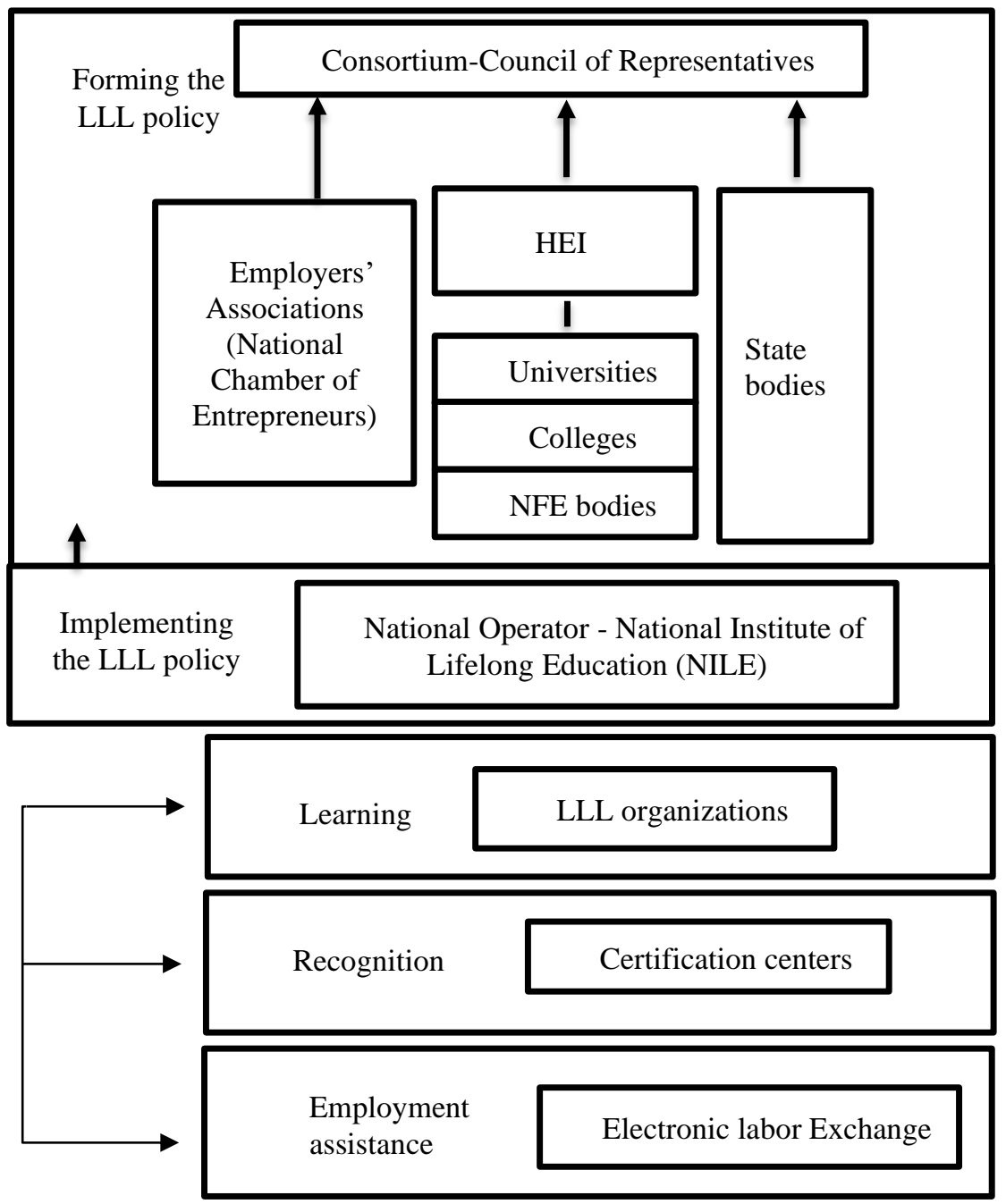

Fig. 3. Institutional structure of the LLL system

The Consortium of organizations (NCE “Atameken", national companies, public associations, universities, colleges, etc.) and state bodies is a collegial body whose task is to form the LLL policy.

To implement the policy of lifelong education, the National Institute of Lifelong Education is being created, which should develop quality assurance tools by administering a system for recording lifelong learning achievements, a skills/ competencies bank, and create a Register of Lifelong Education programs, as well as a Credit and non-credit Accumulation bank to recognize and confirm learning achievements based on modern information technologies. The National Institute of Lifelong Education is the national operator of LLL [56]. 
Institutes of lifelong education at Educational institutions, as well as legal entities, implement educational programs of formal, non-formal and informal education, which should be compatible with the National Framework of Key Cross-cutting competencies for the formation of a personal competences profile (PCP).

Certification centers will conduct an independent certification procedure based on the assessment of PCP for the assignment of qualifications in accordance with professional growth (career progress) according to the Register of Certification centers of specialists.

Resource support for the institutionalization of lifelong education provides for the creation of mechanisms to motivate professional growth of the individual, the development of material and technical equipment and information support.

A united information and educational space and an electronic labor exchange are created on the basis of modern ICT.

\section{Conclusion}

The proposed scenario for the development of LLL system is a platform aimed at creating opportunities for all citizens of Kazakhstan to learn according to their needs and abilities, for their worthy self-realization in society. The objectives of the Concept are consistent with SDG 4 of the UN Sustainable Development Agenda and with Reform 1 of 2025 Strategic Development Plan of the Republic of Kazakhstan.

During the preparation of the work, the international obligations of the Republic of Kazakhstan in this area were analyzed; the positive and negative experience of foreign countries that actively promote and achieve certain successes in the development of lifelong learning; the current situation in the country's education system. Systemic problems were identified in promoting the idea of lifelong learning.

Analysis demonstrated that the system of formal education in the Republic of Kazakhstan has a stable legislative, methodological and methodical basis (which is proved by the results of international studies) and is regulated by State programs for the development of education with appropriate funding. But at the same time, the opportunities of non-formal education are not fully used. Therefore, within the framework of this study, special attention is paid to the development of non-formal, informal education and their integration with the system of formal education, thereby building a single core of lifelong learning.

The effectiveness of the system depends on the improvement of the regulatory and legal framework, as well as on the introduction of new financial mechanisms.

Thus, modeling the processes of the LLL concept will ensure the continuity of different levels of education, the integration of formal, non-formal and informal education, expand access to the profession through flexible tools for recognizing learning outcomes and qualifications, and increase the labor mobility of the population. 


\section{Acknowledgement}

This work is supported by the Committee of science of the Ministry of Education and science of the Republic of Kazakhstan in the frame of the Agreement on implementation of research, scientific-technical project by grant funding.

\section{$9 \quad$ References}

[1] United Nations. (n.d.). Education - United Nations Sustainable Development. United Nations. https://www.un.org/sustainabledevelopment/education/.

[2] UNESCO. (2012). The International Standard Classification of Education (ISCED) [Ebook]. UNESCO Institute for Statistics. https://doi.org/10.15220/978-92-9189-123-8-en

[3] UNESCO. (2017). UNESCO Institute for Lifelong Learning Technical Note. https://uil. unesco.org/fileadmin/keydocuments/LifelongLearning/en/UNESCOTechNotesLLL.pdf

[4] UNESCO. (2016). Education 2030: Incheon Declaration and Framework for Action Towards inclusive and equitable quality education and lifelong learning for all. https://unesdoc.unesco.org/ark:/48223/pf0000245656

[5] EHEA. (2018). Paris Communiqué. https://www.ehea.info/page-ministerial-conference-paris-2018

[6] Commission of the European Communities. (2000). European Communities: A Memorandum on Lifelong Learning (Commission Staff Working Paper). https:// uil.unesco.org/document/european-communities-memorandum-lifelong-learning-issued-2000

[7] EHEA. (n.d.). The Qualifications Framework of the European Higher Education Area. Retrieved April 23, 2021, from http://ehea.info/page-qualification-frameworks

[8] European Commission. The European Qualifications Framework for Lifelong Learning (EQF) Luxembourg: Office for Official Publications of the European Communities 2008 15 pp. - 21 X 29,7 cm ISBN 978-92-79-08474-4

[9] United Nations. (2020, August). Policy Brief: Education During Covid-19 And Beyond. https://doi.org/10.18356/21e7d903-en

[10] Regmi, K.D. Lifelong learning: Foundational models, underlying assumptions and critiques. Int Rev Educ 61, 133-151 (2015). https://doi.org/10.1007/s11159-015-9480-2

[11] Colardyn, D., \& Bjornavold, J. (2004). Validation of formal, non-formal and informal learning: Policy and practices in EU member states. European Journal of Education, 39(1), 6989. https://doi.org/10.1111/j.0141- 8211.2004.00167.x

[12] Constanţa Aurelia Chiţiba, Lifelong Learning Challenges and Opportunities for Traditional Universities, Procedia - Social and Behavioral Sciences, Volume 46, 2012, Pages 19431947, ISSN 1877-0428, https://doi.org/10.1016/j.sbspro.2012.05.408.

[13] Andy Green (2006). Models of Lifelong Learning and the 'knowledge society', Compare: A Journal of Comparative and International Education, 36:3, 307-325, http://doi.org/ $\underline{10.1080 / 03057920600872449}$

[14] Maureen Tam (2012). Lifelong learning for elders in Hong Kong: policy and practice, International Journal of Lifelong Education, 31:2, 157-170. https://doi.org/10.1080/0260 1370.2012 .663805

[15] Watson, L 2003, Lifelong learning in Australia, Evaluations and Investigations Programme, no. 03/13, Department of Education, Science and Training, Canberra. 
[16] Victor C. X. Wang, \& Judith Parker. (2014). Lifelong Learning in China. Revista Internacional de Organizaciones, 12, 71-88. https://www.researchgate.net/publication/ 280023121_Lifelong_Learning_in_China/stats\#fullTextFileContent

[17] Tan, C. (2016). Lifelong learning through the SkillsFuture movement in Singapore: Challenges and prospects. International Journal of Lifelong Education 1-14. https://doi.org/ $\underline{10.1080 / 02601370.2016 .1241833}$

[18] Diana Soares \& Diana Dias (2018): Perspectives of lifelong education in Portuguese higher education: a critical analysis of learning outcomes, International Journal of Lifelong Education. https://doi.org/10.1080/02601370.2018.1559890

[19] Pastor Pérez, Jorge Juan. (2019). New Models Of Education To Boost Lifelong And Autonomous Learning. 3289-3293. 12th annual International Conference of Education, Research and Innovation, ISBN: 978-84-09-14755-7. https://doi.org/10. 21125/iceri.2019 .0833

[20] Asha Kanwar, K. Balasubramanian \& Alexis Carr (2019) Changing the TVET paradigm: new models for lifelong learning, International Journal of Training Research, 17:sup1, 5468. https://doi.org/10.1080/14480220.2019.1629722

[21] Yevhenii Prokopalo, Sylvain Meignier, Olivier Galibert, Lo1c Barrault, \& Anthony Larcher. (2020). Evaluation of Lifelong Learning Systems. Proceedings of the 12th Conference on Language Resources and Evaluation (LREC 2020), 1833-1841. https://www.aclweb. org/anthology/2020.1rec-1.226

[22] Liu, Z.-J., Tretyakova, N., Fedorov, V., Kharakhordina, M. (2020). Digital literacy and digital didactics as the basis for new learning models development. International Journal of Emerging Technologies in Learning, 15 (14), pp. 4-18. https://doi.org/10.3991/ijet.v15i14. $\underline{14669}$

[23] Sharzadin, A., Utebayev, I., Syzdykova, N., Shaushekova, B., Kossybayeva, U., Mukhatayev, A., Kurymbayev, S. (2019) Teaching internship in math teacher education. International Journal of Emerging Technologies in Learning, 14 (12), pp. 57-70. https://doi .org/10.3991/ijet.v14i12.10449

[24] Galustyan, O.V., Borovikova, Y.V., Polivaeva, N.P., Kodirov, B.R., Zhirkova, G.P. (2019) E-learning within the Field of Andragogy. International Journal of Emerging Technologies in Learning, 14 (9), pp. 148-156. https://doi.org/10.3991/ijet.v14i09.10020

[25] Bisovsky, G., Schaffert, S. (2009) Learning and teaching with e-portfolios: Experiences in and challenges for adult education. International Journal of Emerging Technologies in Learning, 4 (1), pp. 13-15. http://dx.doi.org/10.3991/ijet.v4i1.822

[26] Shah, A., Salimullah, K. (2009). Use of Information and Communication Technology (ICT) for effective Open and Distant Learning (ODL). International Journal of Emerging Technologies in Learning, 4 (4), pp. 63-67. http://dx.doi.org/10.3991/ijet.v4i4.1034

[27] The French Republic. (2002, January). Loi n ${ }^{\circ} 2002-73$ du 17 janvier 2002 de modernisation sociale (Law on Social Modernization) (NOR: MESX0000077L). https://www.legifrance. gouv.fr/eli/loi/2002/1/17/MESX0000077L/jo/texte

[28] OECD. (2008). Recognition Of Non-Formal And Informal Learning Country Note For Belgium (Flanders) (Edu/Edpc/Rnfil(2008)2/Part2). Directorate for Education of OECD. https://publicaties.vlaanderen.be/view-file/3373

[29] Patrick Werquin. (2010). Recognising Non-Formal and Informal Learning OUTCOMES, POLICIES AND PRACTICES. https://doi.org/10.1787/9789264063853-en

[30] The Ministry of education and research. (2014). The Estonian Lifelong Learning Strategy 2020. https://www.hm.ee/sites/default/files/estonian_lifelong_strategy.pdf 
[31] Department of Further and Higher Education, Research, Innovation and Science of the Ireland. (2020). The National Further Education and Training (FET) Strategy 2020-2024 [Ebook]. https://www.solas.ie/f/70398/x/64d0718c9e/solas_fet_strategy_web.pdf

[32] Bertelsmann Stiftung, \& Ruud Duvekot. (2015). How informal and non-formal learning is recognised in Europe Netherlands - country report. https://www.bertelsmann-stiftung .de/fileadmin/files/BSt/Publikationen/GrauePublikationen/LL_The_Netherlands_FINAL_ 36Seiten.pdf.

[33] Ministry of education research. (2007). Strategy for Lifelong Learning in Norway (report). https://uil.unesco.org/fileadmin/keydocuments/LifelongLearning/en/NorwayStrategy.pdf

[34] Ministério do Trabalho e da Solidariedade Social. (Ministry of Labor and Social Solidarity, 2007, December 31). Decreto-Lei n.o 396/2007 (Law N396/2007). Diário Da República. https://dre.pt/pesquisa/-/search/628017/details/maximized

[35] The Ministry of Education and Research. (2020, October 15). Legea educației naționale nr. 1/2011 (National Education Law). https://edu.ro/legisla\%C8\%9Bie-organizare-\%C8\%99ifunc $\%$ C $8 \% 9$ Bionare- 0

[36] OECD (2018), Skills Strategy Implementation Guidance for Slovenia: Improving the Governance of Adult Learning, OECD Skills Studies, OECD Publishing, Paris. https://doi. org/10.1787/9789264308459-en, https://doi.org/10.1787/9789264308459-3-en

[37] The Ministry of Education and Vocational Training. (n.d.). Plan estratégico de aprendizaje a lo largo de la vida (Strategic plan for lifelong learning). Https://Www.Educacionyfp.Gob .Es/. Retrieved April 17, 2021, from https://sede.educacion.gob.es/publiventa/d/20676/19/0

[38] The United Kingdom Government. (n.d.). Ofqual Handbook: General Conditions of Recognition. Https://Www.Gov.Uk/. Retrieved April 17, 2021, from https://www.gov.uk Iguidance/ofqual-handbook

[39] Public Law 94-482 ("Education Amendments of 1976”). (1976). U.S. Government Information. https://www.govinfo.gov/content/pkg/STATUTE-90/pdf/STATUTE-90-Pg2081.pdf

[40] The Parliament of Finland. (2017). Laki ammatillisesta koulutuksesta (Law on Professional Training). Finlex Data Bank. https://www.finlex.fi/fi/laki/alkup/2017/20170531

[41] The Australian Qualifications Framework Council. (2013). The Australian Qualifications Framework (second edition 2013). https://www.aqf.edu.au/sites/aqf/files/aqf-2nd-editionjanuary-2013.pdf

[42] Singapore Government Agency. Singapore Workforce Skills Qualifications. (n.d.). Retrieved April 17, 2021, from https://www.ssg.gov.sg/wsq.html?activeAcc=2

[43] Scottish Credit and Qualifications Framework Partnership. (n.d.). Scottish Credit and Qualifications Framework. SCQF Partnership. Retrieved April 17, 2021, from https://scqf. org.uk/about-the-framework/interactive-framework/

[44] National Institute for Lifelong Education, http://www.nile.or.kr/eng/

[45] The National chamber of entrepreneurs of the Republic of Kazakhstan "Atameken", https://atameken.kz/en/

[46] OECD (2018), Education at a Glance 2018: OECD Indicators, OECD Publishing, Paris. http://dx.doi.org/10.1787/eag-2018-en

[47] OECD (2018). The Survey of Adult Skills (PIAAC). Https://Www.Oecd.Org/Skills/Piaac/. Retrieved April 17, 2021, from https://www.oecd.org/skills/piaac/publications/countryspe cificmaterial/PIAAC_Country_Note_Kazakhstan.pdf, https://doi.org/10.1787/f9a05f72-en

[48] OECD (2020), Education at a Glance 2020: OECD Indicators, OECD Publishing, Paris, https://doi.org/10.1787/69096873-en,

[49] OECD (2019), Skills Matter: Additional Results from the Survey of Adult Skills, OECD Skills Studies, OECD Publishing, Paris, https://doi.org/10.1787/1f029d8f-en, https://doi. org/10.1787/be1a9160-en 
[50] National report on the state and development of the education system of the Republic of Kazakhstan (at the end of 2018) / M. Atanaeva, M. Amankazy, G. Nogaybayeva, A. Akhmetzhanova, M. Shakenova, G. Karbaeva, Zh. Dzhumabayeva, N. Kasymbekova, M .Dauliev, D. Abdrasheva, A. Kusidenova. - Nur-Sultan: Ministry of Education and Science of the Republic of Kazakhstan, Information and Analytical Center JSC, 2019. - 364 pages. https://doi.org/10.32523/2616-7174-2019-127-2-8-19

[51] Kz Skills And Jobs Project, The World Bank Group, https://projects.vsemirnyjbank. org/ru/projects-operations/document-detail/P150183?type=projects

[52] The Minister of Education and Science of the Republic of Kazakhstan. (n.d.). On approval of the Rules for the recognition of learning outcomes obtained by adults via non-formal education provided by organizations included in the list of recognized organizations providing non-formal education. Legal Information System of Regulatory Legal Acts of the Republic of Kazakhstan. Retrieved April 24, 2021, from http://adilet.zan.kz/eng/docs/V1 800017588

[53] The Minister of Education and Science of the Republic of Kazakhstan. (n.d.-b). On approval of the Rules for the recognition of organizations providing non-formal education, and the formation of a list of recognized organizations providing non-formal education. Legal Information System of Regulatory Legal Acts of the Republic of Kazakhstan. Retrieved April 24, 2021, from http://adilet.zan.kz/eng/docs/V1800017591

[54] Omirbayev, S. (2021). Organizational and legal aspect of the "lifelong learning" paradigm". In The role of universities in implementing the concept of lifelong learning (pp. 29-37). National Office of the Erasmus+ program in Kazakhstan.

[55] Akhmed-Zaki, D. (2021). Institutional changes to implement the concept of lifelong learning in Kazakhstan. In The role of universities in implementing the concept of lifelong learning (pp. 6-10). National Office of the Erasmus+ program in Kazakhstan.

\section{Authors}

Serik Omirbayev is a Doctor of Economics, Professor, First Vice-Rector of Astana IT University, Nur-Sultan, Kazakhstan.

Darkhan Akhmed-Zaki is a Doctor of Technical Sciences, Professor, Rector Astana IT University, Nur-Sultan, Kazakhstan.

Aidos Mukhatayev is Candidate of Pedagogical Sciences, Associate Professor, Director of the Department of Strategy and Corporate Governing, Astana IT University, Nur-Sultan, Kazakhstan.

Andrii Biloshchytskyi is a Doctor of Technical Sciences, Professor, Vice-Rector for Science and Innovation, Astana IT University, Nur-Sultan, Kazakhstan.

Khanat Kassenov is a Master of Pedagogical Sciences, Compliance Officer, Astana IT University, Nur-Sultan, Kazakhstan.

Adil Faizullin is a Master of Technical Sciences, Director of Strategy and Corporate Governance Department, Astana IT University, Nur-Sultan, Kazakhstan.

Article submitted 2021-05-02. Resubmitted 2021-06-05. Final acceptance 2021-06-06. Final version published as submitted by the authors. 